Authors: P du Toit and

G Ferreira

\title{
THE REGULATION OF THE POSSESSION OF WEAPONS
} AT GATHERINGS

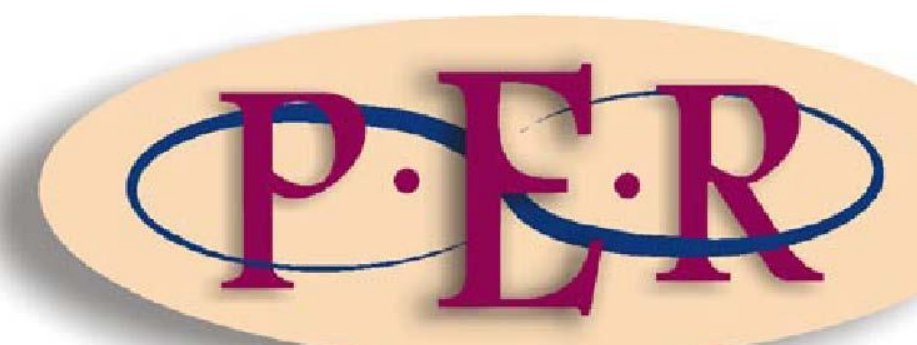

2013 VOLUME 16 No 4

http://dx.doi.org/10.4314/pelj.v16i4.9 


\section{THE REGULATION OF THE POSSESSION OF WEAPONS AT GATHERINGS}

\section{P du Toit* \\ G Ferreira**}

\section{Introduction}

The Constitution guarantees everyone the right, peacefully and unarmed, to assemble, to demonstrate, to picket and to present petitions. ${ }^{1}$ Public demonstrations in South Africa are, however, often accompanied by the wielding of an array of weapons by those taking part therein. These demonstrations often occur in the context of labour disputes. ${ }^{2}$ In this note the lawfulness of the possession of weapons at public gatherings is considered. Particular attention will be given to the impact of the provisions of the Dangerous Weapons Act 15 of 2013, which was recently signed into law. The Act provides for certain prohibitions and restrictions in respect of the possession of a dangerous weapon and it repeals the Dangerous Weapons Act 71 of 1968 as well as the different Dangerous Weapons Acts in operation in the erstwhile TBVC States. The Act also amends the Regulation of Gatherings Act 205 of 1993 to prohibit the possession of any dangerous weapon at a gathering or demonstration. The Regulation of Gatherings Act 205 of 1993 regulates the holding of gatherings and demonstrations at certain places. $^{3}$

Pieter du Toit. B Iuris, LLB (UOFS); LLM (UJ); LLD (NWU). Associate Professor, Faculty of Law, North-West University, Potchefstroom Campus. Email: pieter.dutoit@nwu.ac.za.

** Gerrit Ferreira. B Iuris, LLB (PUCHO); LLM (RAU); LLD (UNISA); LLD (PUCHO). Professor, Faculty of Law, North-West University, Potchefstroom Campus. Email: gerrit.ferreira@nwu.ac.za.

Section 17 Constitution of the Republic of South Africa, 1996.

See for instance Amnesty International Date Unknown www.amnesty.org.

A "demonstration" is defined by the Act as "including any demonstration by one or more persons, but not more than 15 persons, for or against any person, cause, action or failure to take action". A "gathering" means any assembly, concourse or procession of more than 15 persons in or on any public road as defined in the Road Traffic Act 1998 (Act 29 of 1998), or any other public place or premises wholly or partly open to the air - (a) at which the principles, policy, actions or failure to act of any government, political party or political organization, whether or not that party or organization is registered in terms of any applicable law, are discussed, attacked, criticized, promoted or propagated; or (b) held to form pressure groups, to hand over the petitions to any person, or to mobilize or demonstrate support for or opposition to the views, principles, policy, actions or omissions of any person or body of persons or institution, including any government, administration or governmental institution." See s 1 Regulation of Gatherings Act 205 of 1993. 


\section{Prohibition on the possession of dangerous weapons in terms of the Dangerous Weapons Act 71 of 1968}

For the sake of the proper contextualisation of the issue the relevant provisions of the now repealed Dangerous Weapons Act 71 of 1968 will be considered as the point of departure. It provided for certain restrictions in respect of the possession of dangerous weapons. Section 2(1) of the Act read as follows:

Any person who is in possession of any dangerous weapon, or of any object which so resembles a firearm that, under circumstances such as those under which such person is in possession thereof, it is likely to be mistaken for a real firearm, shall be guilty of an offence, unless he is able to prove that he at no time had any intention of using such weapon or object for any unlawful purpose, and shall on conviction be liable to a fine or to imprisonment for a period not exceeding two years.

A "dangerous weapon" was defined as "any object, other than a firearm, which is likely to cause serious bodily injury if it were used to commit an assault". ${ }^{4}$

In $S v$ Adams $^{5}$ it was pointed out that the definition of "dangerous weapon" has caused much difficulty in the interpretation and practical application of the 1968 Act. $^{6}$ The court pointed out that Parliament had been concerned to strike at the source of the unlawful use of weapons, which was endemic in some parts of the country, by extending the definition of a dangerous weapon, and introducing higher penalties for the unlawful possession thereof. The court held that the legislature did not want to cast the net so wide by making it prima facie an offence to be in possession of any object whatsoever which was likely to cause serious bodily injury if it were used to commit an assault.' Nicholas AJA (Botha JA and Galgut AJA concurring) approached the construction of section 2(1) of the Act from the starting point of the ingredients of the offence which it had created. These ingredients were (a) possession of a (b) weapon which is (c) dangerous. ${ }^{8}$ The court held that in its

\footnotetext{
Section 1 Dangerous Weapons Act 71 of 1968.

$S v$ Adams 19864 SA $882($ A).

$S v$ Adams 19864 SA 882 (A) 890B-C, 894C-D.

$S v$ Adams 19864 SA 882 (A) 895D-E.

$S v$ Adams 19864 SA 882 (A) 896D.
} 
ordinary meaning the word "weapon" covered any object which was designed for use as a weapon, for example swords, daggers, bayonets and battle axes, and also any object which, although not designed for use as a weapon, was used or intended to be used as a weapon. ${ }^{9}$ In the case under section 2(1), which penalised mere possession, what had to be considered was whether the object was possessed qua weapon, or for some other reason. That was something that was normally to be inferred from the nature of the object and the circumstances in which it was possessed. ${ }^{10}$ As such the inference could for instance not be drawn that a man going about his daily affairs and carrying a tool to work, or a cricketer carrying his bat, was in possession of such a weapon. On the other hand, the court held, such an inference could be drawn in the case of a man carrying a cane knife during a public disturbance, or a man carrying a sharp chisel concealed in a shebeen. ${ }^{11}$ The state had to prove that the individual charged had been in possession of a weapon. That having been proved, the next step was to determine whether or not it was indeed a dangerous weapon. ${ }^{12}$ In $S v L e o^{13}$ it was held that it was clear that the definition of "dangerous weapon" was not aimed at weapons in general, but at objects that fulfilled two criteria, namely (i) they must have been likely to cause serious bodily injury, and (ii) they must have been capable of being used in an assault. It was therefore necessary to consider both the nature and the qualities of the object, as well as its potential for use in an assault. ${ }^{14}$

Section 2(1) of the 1968 Act clearly placed the burden on the accused to prove that he or she at no time had any intention of using the weapon or object for any unlawful purpose once it was established by the state that he or she had been in possession of a dangerous weapon or any object which so resembles a firearm that it is likely to be mistaken for the real firearm. Snyman ${ }^{15}$ held the view that the onus which the Act had placed on the accused was inconsistent with the right to be

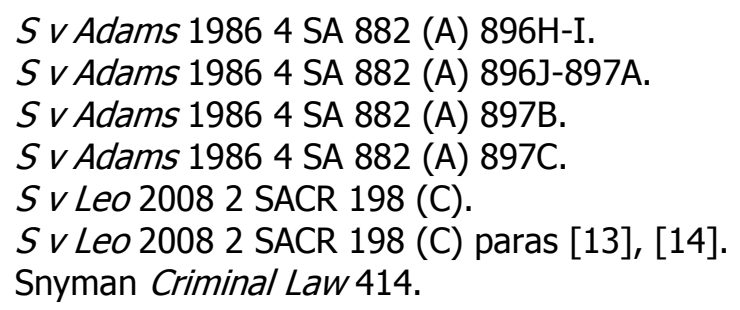


presumed innocent and to remain silent, and therefore unconstitutional. He based his argument on analogous cases dealing with presumptions in other legislation.

\section{The Dangerous Weapons Act 15 of 2013}

The Dangerous Weapons Act of 2013 brings about substantial changes to the law regarding the possession of dangerous weapons. The Act repeals the Dangerous Weapons Act 71 of 1968 and similar pieces of dangerous weapons legislation in operation in the areas of the erstwhile Transkei, Bophuthatswana, Venda and Ciskei. This became necessary as a result of the judgement of the Constitutional Court in $S$ $v$ Thunzi and Mlonzil ${ }^{16}$ where the court called into question the constitutionality of the existence of multiple Dangerous Weapons Acts that operated in different parts of South Africa. The court held that Parliament had not established a uniform system of law governing the use of dangerous weapons throughout South Africa. Instead, it had retained the former TBVC states' laws and amended them to replicate the terms of the 1968 Dangerous Weapons Act in operation in South Africa. ${ }^{17}$

The Constitutional Court also called into question if there was a constitutional obligation on Parliament to establish uniform legislation on the use of dangerous weapons in the Republic. ${ }^{18}$ Since the matter was not properly argued before the court, it inter alia called for further submissions on whether or not the existence of the different Dangerous Weapons Acts in operation in the former TBVC states was constitutionally acceptable. The court required the Speaker of the National Assembly, the Chairperson of the National Council of Provinces and the Minister of Justice and Constitutional Development to notify the court of steps that had been taken in fulfilment of the undertaking to rationalise the Dangerous Weapons Acts of the erstwhile South Africa and the TBVC states. ${ }^{19}$ In the subsequent hearing, Parliament accepted that it had an obligation to effect rationalisation in order to have uniform national legislation regulating the use of dangerous weapons. The

\footnotetext{
S v Thunzi and Mlonzi CCT 81/09 [2010] ZACC 12.

$S v$ Thunzi and Mlonzi CCT 81/09 [2010] ZACC 12 para [65].

$S v$ Thunzi and Mlonzi CCT 81/09 [2010] ZACC 12 para [66].

$S v$ Thunzi and Mlonzi CCT 81/09 [2010] ZACC 12 para [72].
} 
Minister also indicated that the process of rationalisation had begun. ${ }^{20}$ The Dangerous Weapons Act of 2013 therefore addresses the need for this uniform legislation that will apply throughout South Africa.

In the memorandum on the objects of the Bill preceding the Act, a further object is stated, namely that a large number of murders and robberies, as well as other violent crimes, are being committed annually with dangerous weapons such as knives. Imitation firearms have also been found amongst robbery suspects. The Act therefore aims to curb these social evils. ${ }^{21}$ The Preamble of the Act refers to the constitutional right to the security of persons and the right to be free from all forms of violence as well as the right to peaceful assemblies and demonstrations.

The Act prohibits the possession of any dangerous weapon under circumstances which may raise a reasonable suspicion that the person intends to use the dangerous weapon for an unlawful purpose. On conviction the offender faces a fine or imprisonment not exceeding three years. ${ }^{22}$ For purposes of the Act "dangerous weapon" means "any object, other than a firearm, designed as a weapon and capable of producing death or serious bodily harm, if it were used for an unlawful purpose".23

In determining whether a person intends to use the object as a dangerous weapon for an unlawful purpose, the Act provides that all relevant factors must be taken into account. These factors include but are not limited to (a) the place and time where the person is found; (b) the behaviour of the person, including the making of any threat or the display of intimidatory behaviour; (c) the manner in which the object is carried or displayed; (d) whether the possession of the object was in the context of drug dealing, gang association or any organised crime activity or (e) any other relevant factors, including any explanation the person may wish to provide for his or her possession of the object. The last of these factors may, however, not be

$20 \quad S v$ Thunzi and Mlonzi CCT 81/09 [2010] ZACC 27 para [8].

21 Memorandum on the Objects of the Dangerous Weapons Bill, 2012 (GN 606 in GG 34579 of 2 September 2011).

22 Section 3(1) Dangerous Weapons Act 15 of 2013.

23 Section 1 Dangerous Weapons Act 15 of 2013. 
interpreted as an obligation on the person to explain his or her possession of the object. $^{24}$

The Act, however, does not apply to the following activities: the possession of dangerous weapons in pursuit of any lawful employment, duty or activity; ${ }^{25}$ the possession of dangerous weapons during the participation in any religious or cultural activities, or lawful sport, recreation, or entertainment; ${ }^{26}$ or the legitimate collection, display or exhibition of weapons. ${ }^{27}$

The Dangerous Weapons Act also amends section 8(4) of the Regulation of Gatherings Act to provide that no participant at a gathering or demonstration may have in his or her possession (a) any airgun, firearm, imitation firearm or any muzzle-loading firearm, as defined in section 1 of the Firearms Control Act 60 of 2000 , or any object which resembles a firearm and that is likely to be mistaken for a firearm or (b) any dangerous weapon, as defined in the Act. The convenor and marshals appointed in terms of the Gatherings Act must take all reasonable steps to ensure that section 8(4) of the Regulation of Gatherings Act is complied with. ${ }^{28}$

\section{Discussion}

\subsection{The meaning of "possession of dangerous weapons"}

The first question which arises is if a "dangerous weapon" as defined by the Dangerous Weapons Act of 2013 includes an object which, although not designed for use as a weapon, is used or intended to be used as a weapon. This approach was followed by the court in Adams in the interpretation of the meaning of "dangerous weapon" in the Dangerous Weapons Act of $1968 .{ }^{29}$ In an early version of the Bill preceding the Act a "dangerous weapon" was defined as "any object, other

Section 3(2) Dangerous Weapons Act 15 of 2013.

Section 2(a) Dangerous Weapons Act 15 of 2013.

Section 2(b) Dangerous Weapons Act 15 of 2013.

Section 2(c) Dangerous Weapons Act 15 of 2013.

Section 5(a) Dangerous Weapons Act 15 of 2013.

See 3 above. 
than a firearm, designed as a weapon and capable of producing death or serious bodily harm ${ }^{\prime 30}$. The Act, however, simply states that the object must be capable of causing death or inflicting serious bodily harm, if it were used for an unlawful purpose. ${ }^{31}$ In $S$ v Rabako ${ }^{32}$ Musi J (Milton AJ concurring) interpreted "grievous bodily harm" in the context of sentencing in a rape case. They held that "grievous" means nothing more than "really serious". The court held that, if the injury inflicted by the accused on the body of the rape survivor is serious, then it involves the infliction of grievous bodily harm. A serious injury need not necessarily be an injury that is permanent, life-threatening, dangerous or disabling. Whether the injuries were lifethreatening, necessitated hospitalisation or immediate medical attention will generally be relevant to determining the degree of seriousness, but not necessarily the seriousness itself. Whether an injury is deemed to be serious or not will depend on the facts and circumstances of every case. The injury should, however, not be trivial or insignificant.

The drafters of the Act also clearly took cognisance of the interpretation by our courts of the Dangerous Weapons Act of 1968. To ensure that the net of criminal liability is not cast on those who possess the weapon for a lawful purpose, it was held in Adams that a weapon included any object which, although not designed for use as a weapon, was used or intended to be used as a weapon. The 2013 Act prohibits the possession of a weapon under circumstances which may raise a reasonable suspicion that the person intends to use the dangerous weapon for an unlawful purpose..$^{33}$ This section embodies the actus reus of the offence that the state must prove, which includes the objective criterion "under circumstances which may give rise to a reasonable suspicion". Furthermore, as was pointed out above, it was held in Adams that in order to determine whether or not the accused intended to possess the weapon as a weapon, the court had to consider the nature of the object and the circumstances in which it was possessed. The 2013 Act gives detailed guidance as to the factors that a court may consider in determining whether the

Clause 1 Dangerous Weapons Bill [B37-2012].

S 1 Dangerous Weapons Act 15 of 2013.

$S$ v Rabako 20101 SACR 310 (0) para [7].

Section 3(1) Dangerous Weapons Act 15 of 2013. 
accused intended to use the weapon for an unlawful purpose. ${ }^{34}$ Although these factors may guide the court to establish the intention of the person by inferential reasoning, the onus remains on the state to prove the required intention.

The Act does not define the meaning of "possession". The ordinary meaning of the word requires that the individual must exercise physical control or custody over the object (detentio) and have the necessary intent (animus) to exercise such control. ${ }^{35}$

\subsection{The onus on the state}

One of the positive features of the Act is that it no longer places a burden of proof on the accused. In terms of the Dangerous Weapons Act of 1968, once the state proved that the person had been in possession of a dangerous weapon, the accused person had to prove that at no time had he any intention of using the weapon for any unlawful purpose. ${ }^{36}$ In terms of the 2013 Act the state will not only have to prove that the accused person was in possession of the prohibited weapon but also that it was possessed under circumstances which may raise a reasonable suspicion that the person intended to use the prohibited object for an unlawful purpose. Whether the suspicion can be regarded as reasonable or not must be approached in an objective manner. The circumstances giving rise to the suspicion must be such as would ordinarily move a reasonable person to form the suspicion that the person intended to use the prohibited object for an unlawful purpose. ${ }^{37}$

\subsection{Prohibition on possession of weapons at a gathering or demonstration}

The 2013 Act amends the Regulation of Gatherings Act to prohibit the possession of any dangerous weapon at a gathering or demonstration. ${ }^{38}$ The Act also prohibits the

Section 3(2) Dangerous Weapons Act 15 of 2013. See the factors listed in 4 above.

Snyman Criminal Law 412. See also S v Mosoinyane 19981 SACR 583 (T) 591E-593G.

Section 2(1) Dangerous Weapons Act 71 of 1968.

Du Toit et al Commentary 5-11.

Section 5(a) Dangerous Weapons Act 15 of 2013. An early version of the Bill [B37-2012] preceding the Act prohibited not only the possession of a dangerous weapon at a gathering or 
possession at a gathering or demonstration of any airgun, firearm, imitation firearm or any muzzle-loading firearm, as defined in the Firearms Control Act, or any object which resembles a firearm and that is likely to be mistaken for a firearm. A person possessing a firearm with a licence or permit as required by the Firearms Control Act would therefore also be guilty of an offence if he or she possesses the firearm at a gathering or demonstration. The inclusion of an airgun, imitation firearm and muzzle-loading firearm are necessary because these objects are not regarded as firearms for purposes of the Firearms Control Act 60 of 2000, which provides for the system of firearms control. ${ }^{39}$ The Firearms Control Act does, however, create a number of different offences in respect of these objects. Any person who fails to comply with these provisions is guilty of an offence and on conviction liable to a fine not exceeding R20 000 or to imprisonment for a period not exceeding one year or to both such fine and such imprisonment. ${ }^{40}$

The offence created by section 3(1) of the Act (the possession of a dangerous weapon which may raise a reasonable suspicion that the person intends to use the dangerous weapon for an unlawful purpose) must not be confused with the offence created by section 5(a) thereof amending the Regulation of Gatherings Act (possession at a gathering or demonstration of any dangerous weapon as defined by the Dangerous Weapons Act). The definition of a dangerous weapon in the Act does not include the requirement that there must be a reasonable suspicion that the person intended to use the dangerous weapon for an unlawful purpose. The possession of the weapon at a gathering or demonstration is therefore prohibited if the object is capable of causing death or inflicting serious bodily harm if it were used for an unlawful purpose. It does not require a reasonable suspicion that the person intends to use it for an unlawful purpose. According to media reports the Acting Minister in the Presidency for Performance Monitoring and Evaluation, Richard

demonstration, but also "any other object that is likely to cause injury to a person or damage to property".

39 Section 1 read with ss 5(1)(e) and (f) Firearms Control Act 60 of 2000.

40 Section 12(1)(c) Regulation of Gatherings Act 205 of 1993. 
Baloyi, stated that the Act would make the carrying of weapons by protestors "completely illegal". ${ }^{41}$

\subsection{Exceptions to the application of the Act}

In 1992 the Goldstone Commission of Inquiry Regarding the Prevention of Public Violence and Intimidation appointed an international panel of experts to advise one of its committees on the most desirable rules and procedures pertaining to mass demonstrations, marches and picketing. In its report ${ }^{42}$ the panel recommended "a universal prohibition on demonstrators carrying weapons or replicas of weapons or wearing disguises". The South African Constitution in section 17 echoes the same sentiment by providing that "everyone has the right, peacefully and unarmed, to assemble, to demonstrate, to picket and to present petitions". By recognising assemblies, demonstrations, picketing and the presenting of petitions as a right of everyone, the Constitution acknowledges it as an important form of political engagement and as an essential phenomenon in any liberal democracy. ${ }^{43}$

The recommendation by the panel of experts does not make any reference to the kind of weapons that are prohibited or suggest any exceptions to the said prohibition, notwithstanding the fact that the carrying of so-called cultural weapons is a fairly wide-spread phenomenon in South Africa, for example the stick (knobkierie), assegai (spear) and shield carried by Zulu men during certain ceremonies. The Constitution follows a similar approach. It does not define the nature of the terms assembly, demonstration and picketing contained in section 17, nor does it make provision for any exceptions to the ban on the carrying of weapons during these events. However, the Dangerous Weapons Act in section 2 determines that the Act does not apply to the following activities: (a) possession of dangerous weapons in pursuit of any lawful employment, duty or activity; (b) possession of dangerous weapons during the participation in any religious or cultural activities or

All Africa South Africa 2012 allafrica.com.

Heymann (ed) Towards Peaceful Protest 17.

Currie and De Waal Bill of Rights Handbook 396. 
lawful sport, recreation or entertainment or (c) legitimate collection, display or exhibition of weapons.

This provision raises a number of issues. Section 17 of the Constitution requires assemblies, demonstrations, picketing and the presenting of petitions to be unarmed. Unarmed in this sense, it is submitted, should be taken not only to refer to firearms, but also to dangerous weapons other than firearms. The Act does not provide definitions for religious or cultural activities mentioned in section 2 and one can argue that these activities may form part of assemblies, demonstrations, and the presentation of petitions referred to in section 17 of the Constitution. Therefore, section 2 of the Act should not be interpreted to authorise, in conflict with section 17 of the Constitution, the carrying of dangerous weapons during religious and cultural activities. It merely states that the Act is not applicable to the specified events. On the other hand one must keep in mind that the Constitution in sections 30 and 31 grants the right to religious and cultural expression and that a strong argument can be made in favour of the carrying of certain weapons as a form of religious or cultural expression. In this regard it is suggested that a generally acceptable objective definition of terms such as "religious and cultural activities" and "religious and cultural weapons" would be impossible to frame due to the subjective nature thereof. Section 31 states that persons belonging to a cultural or religious community may not be denied the right to enjoy their culture or practise their religion with other members of such a community, and that these rights may not be exercised in a manner inconsistent with any provision of the Bill of Rights. Section 30 explicitly reiterates that everyone has the right to participate in the cultural life of their choice, but that no one may do so in a manner inconsistent with any provision in the Bill of Rights. At the same time the provisions of section 12(1)(c) of the Constitution must also be given practical effect, namely that everyone has the right to freedom and security of the person, including to be free from all forms of violence from either public or private sources. A weighing up of different fundamental rights is thus required, such as the right to religious and cultural expression (which may involve the carrying of weapons and which may have in certain instances the 
potential to erupt into violence) against the right to be free from all forms of violence.

Although the Constitution does not define the concepts of assembly, demonstration, and picketing in section 17, it would seem that the essence of these terms is to be found in their "protesting" or "confrontational" nature. In this regard one must also refer to section 1 of the Regulation of Gatherings Act 205 of 1993, according to which the definitions of the terms "demonstration" and "gathering" clearly display a " "protesting" or "confrontational" nature. It is probably this fact that has led the drafters of the Constitution to require any assembly, demonstration, picketing or presenting of a petition in terms of section 17 to take place "peacefully and unarmed" so as to avoid violent conflict in which weapons are used. It is important to note that certain cultural and religious events may also be "protesting" or "confrontational" in nature (with the concomitant risk of turning violent) and one could argue that these events should therefore probably have been included in the prohibition on the possession of dangerous weapons in section 3 of the Dangerous Weapons Act. However, the fact that section 2 exempts religious or cultural activities (and does not use the words religious and cultural gatherings and demonstrations as in section 4 of an early version of the Bill preceding the Act), ${ }^{44}$ creates the impression that the drafters of the Act had in mind religious and cultural events that are not "protesting" or "confrontational" in nature, and therefore did not include such events in section 3 of the Act, which prohibits the possession of dangerous weapons. In the said previous version of the Act, section 4 explicitly made provision for authorisation to carry dangerous weapons "during a gathering or demonstration, for cultural or religious purposes or historical enactments". The Act excludes religious and cultural activities from the application of the Act, but is silent on the position of historical enactments. It can, however, be argued that section 2 is formulated broadly enough to include historical enactments. In a similar vein it is suggested that historical enactments, as well as lawful employment activities, sport, recreation and entertainment and the legitimate collection, display or exhibition of weapons in terms of section 2 of the Act, would not be in violation of section 17 of 
the Constitution as these kinds of events are normally not "protesting" or "confrontational" in nature, at least not in the sense of running a serious risk of turning into a violent protest or confrontation in which dangerous weapons are used to injure or even kill people. In addition, the events excluded in section 2 would normally be relatively easily identifiable as such and thus need not be defined in the Act. Any attempt to exhaustively describe these concepts would probably create greater legal uncertainty than legal clarification.

It must be pointed out that the discretion to determine whether or not a person intends to use a dangerous weapon for an unlawful purpose contained in section 3 of the Act is fully in line with the decision of the Constitutional Court in Dawood $v$ Minister of Home Affairs 20003 SA 936 (CC) where it was explicitly found that the legislative granting of a discretion must be accompanied by the jurisdictional facts to be taken into account when the discretion is exercised. Although this case dealt with the limitation of a fundamental right by way of discretion, it is suggested that the following finding of the Court is valid also in the current context: ${ }^{45}$

It is an important principle of the rule of law that rules be stated in a clear and accessible manner. ... [I]f broad discretionary powers contain no express constraints, those who are affected by the exercise of the broad discretionary powers, will not know what is relevant to the exercise of those powers or in what circumstances they are entitled to seek relief from an adverse decision.

Section 3 lists the factors to be taken into account when exercising the said discretion as including the time and place where the person is found, the behaviour of the person, the manner in which the person carries or displays the weapon and the question of whether or not the possession of the weapon relates to criminal activity.

45 Dawood v Minister of Home Affairs 20003 SA 936 (CC) para 47. 


\section{Conclusion}

The Dangerous Weapons Act of 2013 addresses two important constitutional concerns. It provides for a uniform system of law governing the use of dangerous weapons for the whole of South Africa and it furthermore no longer places the onus on the individual charged with the offence of the possession of a dangerous weapon that he or she did not have any intention of using the firearm for an unlawful purpose.

The Act also defines the meaning of a dangerous weapon. According to our court's interpretation of the Dangerous Weapons Act 71 of 1968 a dangerous weapon is regarded as an object used or intended to be used as a weapon even if it had not been designed for use as a weapon. However, the Act requires the object to be capable of causing death or inflicting serious bodily harm if it were used for an unlawful purpose. The possession of a dangerous weapon under circumstances which may raise a reasonable suspicion that the person intends to use it for an unlawful purpose attracts criminal liability. The Act also provides a useful set of guidelines to assist courts to determine if a person charged with the offence of the possession of a dangerous weapon had indeed intended to use the weapon for an unlawful purpose. It seems, however, that the Act prohibits the possession of a dangerous weapon at gatherings even if the person carrying the weapon does not intend to use it for an unlawful purpose. The state will, however, have to prove that the accused had the necessary control over the object and the intention to exercise such control, as well as that the object is capable of causing death and inflicting serious bodily harm if it were used for an unlawful purpose.

It is suggested that the exclusions contained in section 2 of the Act are acceptable if the religious and cultural events referred to in that section are not of a "protesting" or "confrontational" nature. If such events are indeed "protesting" or "confrontational" in nature, they are covered by section 17 of the Constitution (which authorises only peaceful and unarmed assembly, demonstration, picketing and presenting of petitions). The possession of dangerous weapons at religious and 
cultural events which display a "protesting" or "confrontational" character runs a serious risk of turning violent, and may result in a violation of section 12(1)(c) of the Constitution, which embodies the right of everyone to be free from all forms of violence. 


\section{Bibliography}

Currie and De Waal Bill of Rights Handbook

Currie I and De Waal J The Bill of Rights Handbook $5^{\text {th }}$ ed (Juta Lansdowne 2005)

Du Toit et al Commentary

Du Toit E et al Commentary on the Criminal Procedure Act Revision Service 48 (2012) (Juta Claremont 1987)

Heymann (ed) Towards Peaceful Protest

Heymann PB (ed) Towards Peaceful Protest in South Africa: Testimony of Multinational Panel Regarding Lawful Control of Demonstrations in the Republic of South Africa before the Commission of Inquiry Regarding the Prevention of Public Violence and Intimidation (HSRC Pretoria 1992)

Snyman Criminal Law

Snyman CR Criminal Law $4^{\text {th }}$ ed (LexisNexis Durban 2002)

\section{Register of legislation}

Constitution of the Republic of South Africa, 1996

Dangerous Weapons Act 71 of 1968

Dangerous Weapons Act 15 of 2013

Firearms Control Act 60 of 2000

Regulation of Gatherings Act 205 van 1993

\section{Register of government publications}

Dangerous Weapons Bill [B37 of 2012]

Memorandum on the Objects of the Dangerous Weapons Bill, 2012 (GN 606 in GG 34579 of 2 September 2011) 


\section{Register of case law}

Dawood v Minister of Home Affairs 20003 SA 936 (CC)

$S$ v Adams 19864 SA 882 (A)

$S v$ Leo 20082 SACR 198 (C)

$S$ v Mosoinyane 19981 SACR 583 (T)

S v Rabako 20101 SACR 310 (O)

$S$ v Thunzi and Mlonzi CCT 81/09 [2010] ZACC 12

$S$ v Thunzi and Mlonzi CCT 81/09 [2010] ZACC 27

\section{Register of internet sources}

All Africa South Africa 2012 allafrica.com

All Africa South Africa 2012 Cabinet approves Draft Dangerous Weapons Bill http://allafrica.com/stories/201210120036.html [date of use 12 Nov 2012]

Amnesty International Date Unknown www.amnesty.org

Amnesty International Date Unknown South Africa: Judge Must Oversee Mine Protesting Deaths http://www.amnesty.org/en/news/south-africa-judge-mustoversee-probe-mine-protest-deaths [date of use 13 Nov 2012] 